\title{
Integrated Information Circle: The Challenge of Integrating the Civil and Military Police
}

\author{
Círculo Integrado de Informação: O Desafio de Integração das Polícias \\ Civil e Militar
}

Discipline: Public Administration, Public Security

\section{PRESENTATION}

In June 2015, due to the interpersonal relationships maintained with professionals of public security, civil society actors, and public bodies, Dr. Gabriel Ferrando and the Major Felipe Carvalho Barreto were invited to attend a meeting at the Under-secretariat of Education, Valorization, and Prevention (SSEVP) of the Secretariat of State for Security (SESEG) of Rio de Janeiro, in order to discuss the opportunity to create a course of criminal analysis.

At that time, Dr. Gabriel Ferrando was the chief delegate of the 11th DP Rocinha and Major Felipe Carvalho Barreto acted as superintendent of intelligence of the Pacification Police Coordination (CPP) of the military police of the state of Rio de Janeiro (PMERJ). In addition to Dr. Gabriel and Major Barreto, others participated in the meeting: representatives of the SSEVP, the undersecretary of intelligence (SSINT) of the SESEG, and the commander of the Pacifying Police Unit (UPP) Rocinha, Major Pazini.

Participants concluded that before proposing a criminal analysis course, it was necessary to create spaces for the police station and the UPP to exchange information about the criminal dynamics of the area continuously and in time for operational reorientation of staff police officers from both agencies. The meeting ended with a referral: a meeting would be scheduled to present to Rio de Janeiro's security secretary, Dr. Mariano Beltrame, a proposal to create a protocol for the exchange of information between police forces, to be initially tested by the UPP and DP Rocinha.

\footnotetext{
* Corresponding Author.

1. Fundação Centro Estadual de Estatísticas, Pesquisas e Formação de Servidores Públicos do Rio de Janeiro, Escola de Gestão e Políicas Públicas, Rio de Janeiro, RJ, Brazil.

2. Universidade Federal do Rio de Janeiro, Instituto COPPEAD de Administração, Rio de Janeiro, RJ, Brazil.

$1^{\text {st }}$ round
$2^{\text {nd }}$ round


It was then suggested that a meeting be held in October, with the participation of the secretary of security, representatives of SSINT and SSEVP, the undersecretary of Planning and Operational Integration (SSPIO) of SESEG, the coordinating colonel of the CPP, the delegate director of the Police Academy Sylvio Terra (ACADEPOL), the commander of UPP Rocinha, in addition to Major Barreto and Dr. Gabriel, who would have the challenge of presenting the proposal, convince the authorities of the project's potential, and obtain authorization to start.

However, one concern seemed to mainly trouble locality managers, more directly involved: once authorized, how to make the integration, from the exchange of information, an institutionalized action, perennial and independent of the interpersonal relationship of local actors?

\section{BACKGROUND}

The scenario is the Rocinha slum, located between the neighborhoods of Gávea and São Conrado, with a population of 70,491 inhabitants. The community was the 28th in the municipality of Rio de Janeiro to have a Pacifying Police Unit (UPP) deployed on September 29, 2012, after an occupation process by the security forces started on December 13, $2011^{1}$.

As provided for in the constitutional text, in its article 144 (see Annex 1), overt policing and public order preservation work was carried out by military police officers stationed at UPP Rocinha, while investigative and judicial police work was carried out by civil police officers of the 15th DP - Gávea and other judicial police units (UPJ) when necessary.

The challenges to the police forces were represented by the figures released by the Public Security Institute (ISP), which indicated a significant increase in attempted homicides and intentional bodily harm as of early $2012^{2}$.

The difficulties in reducing these indicators were compounded by the lack of other public services, low income, and quality of housing, among other items taken into account to attribute to Rocinha one of the lowest social development indexes (IDS) in the city of Rio de Janeiro ${ }^{3}$. Added to this scenario was the intense activity of criminal groups that sought to establish and/ or consolidate illegal markets for protection and drug trafficking.

In addition to this adverse context for the performance of the security forces, in July 2013, the pacification project eroded significantly in its legitimacy with the population. This was motivated when resident
Amarildo Dias de Souza had his whereabouts unknown after being seen boarding a military police vehicle. The episode took place during Operation Peace Armed on the 13th and 14th of that month. The country was stormed by the question 'Where's Amarildo?,' which gained strength during the popular demonstrations of 2013 - widely reported by the media - and achieved worldwide repercussions. As a result of this action, Judge Daniella Alvarez Prado, of the 35 th Criminal Court of the capital, condemned 12 of the 25 military police officers involved in the case for crimes of torture followed by death, concealment of a corpse, and procedural fraud ${ }^{4}$.

A few months later, SESEG and the civil police of the state of Rio de Janeiro (PCERJ) announced a strategy that aimed to support the search for the legitimacy of police action over pacified territories. In December 2013, two police stations were opened for specific operations in Rocinha (11th DP) and Complexo do Alemão (45th DP).

This and other actions indicated that the control of crime in Rocinha was a priority for public security authorities and the main issue discussed among managers was the study of which strategies should be adopted in the short, medium, and long term.

Among numerous alternatives that were discussed and carried out by the managers of public security institutions, one was the 'Integrated Information Circle,' a project that took place between June 2015 and December 2016, involving the Pacifying Police Unit of Rocinha (28th UPP - Rocinha) of the military police of the state of Rio de Janeiro (PMERJ) and the Rocinha Police Station (11th DP - Rocinha) of civil police of the same state (PCERJ), which was developed to integrate the two police bodies through the exchange of information.

The representatives of the highest level of police institutions and of the State Secretariat for Security accompanied the project, but it was the managers of the local units, supported by SESEG advisors, who shaped it and gave its applicability. Among these agents, two stood out due to their integrative and innovative professional profile, Dr. Gabriel Ferrando - precinct police chief of the 11th DP Rocinha - and Major Felipe Carvalho Barreto - who throughout the process served as intelligence superintendent of the Peacekeeping Police Coordination (CPP).

These professionals identified that the reduced exchange of information between police agencies that act on the 'tip of the line' is one of the elements that make the provision of police service by both institutions difficult in different degrees. 


\section{INTEGRATION FOR AFFINITY BETWEEN MANAGERS}

\section{The PMERJ officer}

Based on the idea that information flows and that the qualification of intelligence data is fundamental to the decision-making process in any planning, intelligence centers were created in each UPP, constituted by a police officer trained to collect data and receive information related to criminal dynamics and their flows of people and goods in the region.

These nuclei were connected through technical channels directly with the Intelligence Division of $\mathrm{CPP}$, and this division was articulated with the Military Police Intelligence Coordination (CIPM), which in turn interacted with the Under-secretariat of Intelligence of the State Secretariat for Security (SSINT/SESEG).

Due to the creation of this intelligence division of the CPP, Major Felipe Carvalho Barreto, in the military police since 2001, was invited to lead this area in 2015, leaving the role of advisor to the SESEG Secretariat for Planning and Operational Integration (SSPIO) that he took over in 2014 after the work carried out at UPP Macacos, where he had outstanding performance.

During his time as UPP commander, the officer demonstrated that he had a profile aimed at integrating police forces, which produced excellent results during his time in command at UPP Macacos, such as the partnership with the 20th DP. Regarding this experience, the officer commented: "It was an unforgettable victory. I never imagined that with the information that the military police shared, one could contribute to such a detailed investigation. This work generated 65 warrants, 12 of which were carried out at UPP Macacos itself. The impact on the population was formidable. It was a joint operation between police officers from the police station and the UPP."

During the period in which he worked in the CPP intelligence area, the major learned about the work carried out by another manager in the Rocinha area, Dr. Gabriel Ferrando, holder of the 11th DP, together with the commander of the local UPP. The elements that would allow the pilot project for the Integrated Information Circle began to be aligned.

\section{The PCERJ precinct police chief}

As a way of improving the work carried out by the civil police in areas with UPP, a process was initiated in 2013 aimed at setting up police stations for specific action on pacified territories. Thus, the state government inaugurated in December 2013 the Rocinha judicial police station (11th DP), and its first full precinct police chief was Dr. Gabriel Ferrando.

It is worth saying that this police station, unlike the others, would have only one area under its jurisdiction. Rocinha previously had its occurrences attended by the police station of Gávea - 15th DP - , and after the 11th DP, the community would have an exclusive judicial police unit.

Precinct police chief Gabriel Ferrando had joined the civil police in 2008, and before taking on the 11th DP he was already recognized for the work carried out in Itaipu, Niterói district, as a holder of the 81 st DP, where he promoted the integration of efforts with the military police, the federal police and the city hall. This characteristic feature focused on integration contributed to his nomination as the precinct police chief for the inauguration of the Rocinha unit.

In an interview granted to the press, already a month ahead of the police station, Dr. Gabriel pointed out the importance of considering all the elements that could strengthen the construction of police investigations: "It takes intelligence action. We are cataloging information and analyzing it. Rocinha is now in a process of pacification, and there are pockets of resistance. Let's understand why there are, where they are, who the people are. And from there we will capture them. This requires time because arrest warrants and investigations must have a consistent body of evidence so that these elements are not arrested and acquitted afterward"s.

To collect this information, Dr. Gabriel sought to approach the UPP Rocinha command, first with Major Priscilla de Oliveira Azevedo, and then with Major Sidnei Pazini who replaced her.

According to Dr. Gabriel, this proximity allowed both the 11th DP and UPP Rocinha managers to recognize that the number of confrontations between military police officers and criminals increased as the number of arrests warrants remained low or even reduced. A personal effort between the two managers to facilitate the exchange of information between their officers was made, and the partnership between the operating agents was constantly encouraged.

\section{THE OPPORTUNITY}

The request made by SSPIO for a criminal analysis course that could be carried out in an integrated manner by the police, which was directed to the Under-secretariat of Education, Valorization, and Prevention of the State 
Secretariat for Security (SSEVP/SESEG), ended up being the opportunity to a bigger initiative.

Thus, an agenda was developed at SSEVP for preliminary alignment of what the requested training would be like, with the presence of members of CPP, SSEVP, SSPIO, and SSINTE. On that occasion, Major Barreto, representing the CPP, mentioned the work that he accompanied and was developed by Dr. Gabriel at Rocinha in partnership with the UPP, as a possible starting point for the intended training for dealing with integrated approaches with the UPP and aimed at analyzing the criminal situation in Rocinha.

The proposal was accepted and, in a new meeting at SSEVP, weeks later, with the same participants of the last meeting, but now with the presence of Dr. Gabriel and the director of ACADEPOL, Dr. Jéssica Oliveira de Almeida, the precinct police chief, presented what has been implemented in the Rocinha area, in partnership with the UPP commander, through four topics.

The first explained the partnership between the managers of the 11th DP and the UPP sought to make civilian and military police officers exchange more information, whatever they were, on an ongoing basis and with the highest possible quality, maintaining the institutional flows of each agency, but speeding up the circulation of this information among the operators of each unit.

Then, it was brought the general idea of creating conditions for the military police to receive information from the police station about warrants to be served, movements of criminals, areas with greater records of police occurrences, guidance on the best way to preserve the evidence, in addition to direct contact with investigators and precinct police chief. At the same time, the civil police would come to know the dynamics of the community through the greater capillarity of the military police on the ground, receiving reports and other elements that could, together, strengthen investigations.

Soon after, one of the expected results was indicated, which would be, in theory, an increase in the number of arrest warrants, together with a reduction in random armed clashes, since a greater number of planned operations would reduce this risk. Information about prisons would be shared by the precinct police chief with the military police officers who assisted in the collection of information, and the criminal would be jailed for a longer time, since he would not be forwarded due to a flagrant arrest, which is generally more precarious, reducing the risk of military police officers once again confront the same criminal.

The fourth topic mentioned that the project could therefore be measured by monitoring the number of armed clashes between security forces and criminals, and the number of arrest warrants issued and served in the area.
The group approved the proposal. Major Barreto and Dr. Gabriel accepted the challenge of making the presentation together to the authorities. The meeting took place weeks later with the presence of the security secretary, Dr. Mariano Beltrame, the peacekeeping police coordinator, Colonel Laviano, to obtain the endorsement of that authority for the execution of the project in an institutional manner at UPP Rocinha, since to the civil police there was already this authorization, and with the participation of UPP commander Major Pazini. On the occasion, the general concept of the Integrated Information Circle was presented: "The immersion in the military police's terrain, provided by the permanent occupation in the environment, enables the perception of innumerable information elements. The targeted capture of these reports and their sharing will act to reveal members of the criminality covered by anonymity, in addition to a better understanding of the new criminal dynamics. The findings achieved with this exchange of information, combined with the sharing of arrest warrants by the DP with those who assisted in the collection of information, will contribute to the reduction of the harmfulness of police operations and an increase in their productivity and efficiency brought about by the increase in integrated operations. and planned for imprisonment by court order, reducing arrests for a flagrant offense, which generally exposes the military police and the community more."

Dr. Gabriel presented on the occasion a mapping prepared by the 11th DP - Rocinha that indicated the high number of confrontations, mostly with the same dynamic: "military police, when on patrol, saw — or were seen by marginals who carried out shots against the garrison."

The presentation sought to sensitize the authorities that the greater the exchange of information, in theory, the greater the possibility of planned operations and, thus, the smaller the number of confrontations during routine patrols. At the same time, the probability of issuing arrest warrants will be more likely based on investigations better informed because of the information shared between the agencies, with the joint enforcement of these arrest warrants by the civil and military police involved in the collection of information.

The project was approved by the authorities and had the beginning marked with the realization of a workshop at ACADEPOL (see, in Annex 2, the Joint Resolution of the Secretariat for Security and the Secretariat of Social Communication, which decentralizes the execution of credits budgets for carrying out the workshop "Integrated information circle: a process of integration of PCERJ and PMERJ"), with the presence of the secretary of security and other authorities.

During one day, forty-seven military police officers and ten civil police inspectors, all stationed in Rocinha, listened to their managers and exchanged contacts. Access 
and information flow were established among managers and agreed with the rest of the staff.

According to the speeches of the speakers Major Barreto and Dr. Gabriel, based on these adjustments, the aim would be to avoid random and unplanned confrontations as much as possible, thus reducing the victimization of residents and police, as well as increasing and strengthening the number of arrest warrants. With this, it was expected to reduce the arrests in flagrant offense and to increase those resulting from judicial orders in which the arrests would be made jointly by the civil police and the military police, which would contribute with the information for the warrant's expedition.

Major Barreto clarified how he perceived the integration between the agencies through the exchange of information: "Information, as it is being placed in this project and intelligence, are complementary things. It is not entering the area of intelligence, where there are degrees of secrecy in what is processed. I say that the goal is not to compete with Public Security Intelligence, which I understand to be another type of activity, but to focus on what is collected at the end and that can be a source for both intelligence and the police station and military police unit to plan their actions, as in problem-oriented policing itself (POP). What matters is how the information is collected by the agent at the end, and how it is processed. This information can serve everyone, it can feed the technical intelligence channels, the UPP commander, and the head of the police station, without having to be mutually exclusive, and this exchange can contribute to improving everyone's results. We note that the police station has more quantitative information from the ROs, and the military police unit has more qualitative information because of the capillarity and the day-to-day presence of policing in the community. One information complements the other and can generate better results if shared promptly."

In addition, Dr. Gabriel explained: "we have to look for projects that foster integration, with a serious, technical discussion, without demagogy, and without vanities. With each institution working within its expertise, offering the best of each.”.

\section{THE FIRST RESULTS}

With these premises in mind, the first results began to appear in the Rocinha area. As occurred at the time of Major Barreto at the head of UPP Macacos in partnership with the 20th DP, an investigation was opened by Dr. Gabriel and strengthened by information from the military police, and from a joint operation, it was possible to identify countless criminals, taking them from anonymity, with videos and other evidence. This generated work so well articulated that the Public Ministry praised the technique used and the way of working, suggesting it as a possible protocol to be used by the institutions.

As a more objective example of the exchange of information idealized by the project and the results it could generate, Dr. Gabriel reported on December 11, 2015 an occurrence of the 11th DP - Rocinha in particular: "Police officers of the unit, today, were successful in apprehending [the individual's name was withheld], due to the fulfillment of a search and seizure warrant for the crime of attempted murder and association for trafficking. The said national was captured at the Miguel Couto Hospital when it was discovered that he was hospitalized there due to injuries caused by PAFs. The same is described as a participant in countless clashes in the Rocinha community, exercising the function of 'trafficking soldier.' The discovery of his whereabouts was also helped by the exchange of information with UPP Rocinha police officers, who received reports and photos of the national admitted to the hospital and passed them on to the unit. Congratulations to the policemen involved, especially the soldier Fernandes from UPP Rocinha, who passed the information on to the unit, being the first cane of the Integrated Information Circle, a pilot project taken over by the 11th DP — Rocinha and UPP da Rocinha, with support from the CPP."

\section{LACK OF BREATH}

New working meetings with the participation of the managers of both police and SESEG were necessary, but, despite the promising start, they did not occur. Changes were made to managers in the secretariat and civil and military police and no other workshops were held.

Dr. Gabriel commented: "in practice, we had resistance, due to lack of disclosure, the involvement of other managers, it was very much in the hands of those who were in the project, and with the changes in command, the project lost breath." In turn, Major Barreto said that "there were not many results because changes occurred, I left CPP and went on another mission, Dr. Gabriel also left, the project did not follow. I realized that the work is very much in the private initiative. The difficulty is to bring institutionality."

Major Barreto was transferred from his position at CPP to the general staff of PMERJ, departing from the project in 2016 and, in November of the same year, Dr. Gabriel assumed another title in the 12th DP (Copacabana).

Between June 2015 and December 2016, the Integrated Information Circle consisted of the following actions: articulation between the protagonists of the case and authorities; publication of a resolution (Annex 2); holding a training workshop; meetings between police officers from the police station and the UPP in the Rocinha region at random, which facilitated the arrest of offenders; and, as a 
main result, the conclusion of a police inquiry that used the information from the Integrated Circle to generate the arrest of several criminals. Despite the project's trajectory and the first results achieved, the Integrated Circle of Information was not consolidated as an action to promote integration.

A few years later, the Secretariat of State for Security was dissolved, on January 1, 2019, under the argument that the folder did not effectively promote the integration between the police. In place of SESEG, the civil and military police were made Secretariats of State, according to Decree No. 46.544 .

At the time the project was carried out — and in recent interviews -, Dr. Gabriel, Major Barreto, and others involved in the action shared the same concerns: considering the organizational and cultural environment of the police, how to make that the partnership for the exchange of information is institutional and does not depend on personal relationships between managers?

\section{NOTES}

1. http://www.ispdados.rj.gov.br/UPP.html, retrieved on april 25,2018

2. http://www.ispdados.rj.gov.br/UPP.html, retrieved on april 25,2018

3. https:/www.data.rio/documents/fa85ddc76a524380ad7fo60e3006ee97/ about retrieved on april 26, 2018.

4. G1 Rio (2016, December 01). Caso Amarildo: Juíza condena 12 dos 25 policiais militares acusados. G1. Retrieved from http:/g1.globo.com/rio-de-janeiro/noticia/2016/02/casoamarildo-juiza-condena-13-dos-25-policiais-militaresacusados.html

5. Otoni, A. C. (2014, February 05). Novo delegado da Rocinha aposta na integração com a comunidade. $O$ Globo. Retrieved from https://oglobo.globo.com/rio/ bairros/novo-delegado-da-rocinha-aposta-na-integracaocom-comunidade-11503802\#ixzz5GiFh8Axw 


\section{ANNEX 1}

\section{Art. 144 of the 1988 Constitution of the Federative Republic of Brazil}

144. Public security, the duty of the state, the right and responsibility of all, is exercised for the preservation of public order, and the safety of persons and property, through the following bodies:

Art.

I - federal police;

II — federal highway police;

III — federal railway police;

IV — civil police;

$\mathrm{V}$ - military police and military fire departments.

VI — federal, state, and district criminal police.

$\S 1$ The federal police, established by law as a permanent body, organized and maintained by the Union and structured in a career, are intended to:

$[\ldots]$

$\$ 2$ The federal highway police, a permanent body, organized and maintained by the Union and structured in a career, is intended, in the form of the law, for overt patrolling of federal highways.

$\$ 3$ The federal railway police, a permanent organ, organized and maintained by the Union and structured in a career, is intended, in the form of the law, for overt patrolling of the federal railways.

$\$ 4$ The civil police, headed by career precinct police chiefs, is responsible, except for the competence of the Union, for the functions of the judicial police and the investigation of criminal offenses, except for the military.

$\$ 5$ The military police is responsible for the overt police and the preservation of public order; military fire brigades, in addition to the duties defined by law, are responsible for carrying out civil defense activities.

$\$ 5$-A. The criminal police, linked to the administrative body of the penal system of the federative unit to which they belong, is responsible for the security of penal establishments.

$\$ 6$ The military police and military fire brigades, auxiliary forces, and army reserve are subordinate, together with the civil police and the state and district criminal police, to the Governors of the States, the Federal District, and the Territories.

$\$ 7$ The law will discipline the organization and functioning of the bodies responsible for public security, to guarantee the efficiency of their activities.

$\$ 8$ Municipalities may appoint municipal guards to protect their goods, services, and facilities, as provided by law.

$\$ 9$ The remuneration of police officers who are members of the bodies listed in this article will be fixed in the form of $\$ 4$ of art. 39 .

$\$ 10$. Road safety exercised to preserve public order and the safety of people and their property on public roads:

$[\ldots]$ 


\section{ANNEX 2}

\section{Secretariat of State for Security \\ ACT OF THE SECRETARY AND UNDER SECRETARY \\ JOINT RESOLUTION SESEG/SSCS NO. 191 OF NOVEMBER 30, 2015}

Decentralizes the execution of budget credits in the form you specify.

THE SECRETARY OF STATE OF SECURITY AND THE UNDER SECRETARY OF SOCIAL COMMUNICATION OF CASA CIVIL, in the use of their legal attributions ..., and because of what is contained in Administrative Proceeding No. E-09/009/79/2015,

RESOLVE:

Art. 1 - Decentralize the execution of budget credit, as follows specified: integration.

I - OBJECT - Realization of the Workshop - Integrated information circle: a process of PCRJ and PMERJ $[\ldots]$

Art. 2 - This Joint Resolution enters into force on the date of its publication, revoked provisions to the contrary.

Rio de Janeiro, November 30, 2015.

\section{JOSÉ MARIANO BENINCÁ BELTRAME}

Secretary of State for Security

\section{CARLOS ALBERTO YOUNG TOLOMEI DE ARAÚJO \\ Undersecretary of Social Communication}

Source: Joint SESEG/SSCS Resolution No. 191 of November 30, 2015. Official Gazette of the State of Rio de Janeiro. Retrieved from https://www.jusbrasil.com.br/diarios/106236893/doerj-poder-executivo-14-12-2015-pg-7 


\section{ANNEX 3}

\section{GLOSSARY}

ACADEPOL: Civil Police Academy Sylvio Terra

CIPM: Intelligence Coordination of the Military Police of the State of Rio de Janeiro

CPP: Pacifying Police Coordination of the Military Police of the State of Rio de January

DP: Civil police station

IDS: Social Development Index

ISP: Public Security Institute

PAF: Firearm projectile

PCERJ: Civil Police of the State of Rio de Janeiro

PMERJ: Military Police of the State of Rio de Janeiro

POP: Problem-oriented policing

RO: Record of occurrence in civil police station

SESEG: Secretariat of State for Security of Rio de Janeiro

SSEVP: Under-secretariat of Education, Valorization, and Prevention of the State Secretariat for Security of Rio de Janeiro

SSINT: Under-secretariat of Intelligence of the State Secretariat for Security of Rio de January

SSPIO: Under-secretariat of Planning and Operational Integration of the State Secretariat for Security of Rio de Janeiro

UPP: Pacifying police unit 


\section{ABSTRACT}

Context: the case narrates the creation of the Integrated Information Circle, a pilot project that took place in an area limited to the Rocinha community, led by managers of the civil and military police, which was carried out through a partnership between the 11th DP - Rocinha and the 28th UPP - Rocinha. This action sought to develop protocols for the exchange of information in a continuous, effective, and, above all, institutionalized manner between local police agencies. However, despite the good results achieved, the initiative has not been consolidated. Methodology: the information was collected from secondary data and interviews from the managers who participated in the process - Dr. Gabriel Ferrando, chief of the 11th DP, and Major Felipe Carvalho Barreto, then intelligence superintendent of the Pacifying Police Coordination (CPP). Objectives: To discuss how the civil and military police organize and act. Results: development of analyzes on aspects related to the organization and culture of police institutions about the theme of integration. Conclusion: the case allows us to understand the limits and potential of integration between the police, based on the discussion about the possible reasons why the Integrated Information Circle has been discontinued.

Keywords: intelligence; institutionalization; integration; civil police; military police.

\section{EDUCATIONAL OBJECTIVES}

This case was developed to stimulate discussion about the constitutional role of the military police and civil police in relation to the limits and potential of integrated action between these agencies at the operational and strategic levels.

It is expected, at the end of the case discussion, that the students will be able to reach the following learning objectives: (a) identify limits and potential for institutionalizing practices that promote changes in the organizational processes of the police; (b) discuss about how the culture, organization, and constitutional attribution of each agency contribute to resistance to the exchange of information between operational units; (c) propose dynamics that can contribute to the improvement of information exchange between police forces at the operational and strategic levels, including contributions from the communities where they operate.

\section{RESUMO}

Contexto: o caso narra a criação do Círculo Integrado de Informação, projeto-piloto que ocorreu em uma área circunscrita à comunidade da Rocinha, capitaneada por gestores das Polícias Civil e Militar, que foi executado por meio de parceria entre a $11^{\text {a }} \mathrm{DP}$ - Rocinha e a $28^{\mathrm{a}} \mathrm{UPP}$ - Rocinha. Essa açáo buscava desenvolver protocolos para a troca de informaçóes de modo contínuo, efetivo e, sobretudo, institucionalizado entre as agências policiais locais. Entretanto, apesar de bons resultados alcançados, a iniciativa não se consolidou. Metodologia: as informaçóes foram coletadas a partir de dados secundários e entrevistas dos gestores que participaram do processo - Dr. Gabriel Ferrando, titular da 11 ${ }^{\text {a }}$ DP, e Major Felipe Carvalho Barreto, então superintendente de Inteligência da Coordenadoria de Polícia Pacificadora (CPP). Objetivos: discutir como as Polícias Civil e Militar se organizam e atuam. Resultados: desenvolvimento de análises sobre aspectos relacionados à organização e cultura das instituiçôes policiais em relação ao tema integração. Conclusáo: o caso permite compreender limites e potencialidades da integraçáo entre as polícias, tendo por base a discussáo sobre as possíveis razões de o Círculo Integrado de Informaçóes ter sido descontinuado.

Palavras-chave: inteligência; institucionalização; integração; Polícia Civil; Polícia Militar.

\section{INFORMATION SOURCES}

The information used was collected from primary and secondary sources. Among the primary sources, two managers directly involved at the time with the experience presented in the case were heard, the precinct police chief of the 11th DP - Rocinha, Dr. Gabriel Ferrando, and the superintendent of intelligence of the Pacifying Police Coordination, Major Felipe Carvalho Barreto. Secondary sources were technical reports, newspaper articles, and websites.

\section{DISCIPLINES AND TARGET AUDIENCE}

This case was developed to discuss how the civil and military police are organized and act, showing difficulties to institutionalize practices that promote change in 
organizations, and providing itselffor use in disciplines related to Organization and Police Culture, Strategic Planning and Decision-Making in undergraduate courses or postgraduate in Public Administration. It is also recommended for the subjects focused on studies in intelligence, management, and leadership in environments inserted in the system of public safety and criminal justice.

\section{TEACHING PLAN}

This teaching case is a didactic tool that was designed to enable the learning through an inductive process. If students are not familiar with the institutional environment of the civil and military police, it is recommended the previous reading of the following materials: "Chapter VII Challenges and lessons learned from the pacification policy" of the book Pacifying Police Unit - UPP: from the origin of the program to the pacification policy (Secretaria de Estado de Segurança do Rio de Janeiro - SESEG [SESEG], 2015); pages 94 to 101 of the article "The integration of the military police and civil police of the state of Amazonas with the advent the public safety revitalization plan" (Mathias, 2012); and pages 168 to 174 of the article "Citizen security: Forms of citizen involvement and propensity to co-produce public safety in the Federal District" (Martins, Farias, \& Angelo, 2019). It is also expected that students, in general, know some aspects of institutional theory, and for this we indicate reading pages 64 to 71 of the article "An introduction to institutional theory from the sociological point of view" (Chaerki, Ribeiro, \& Ferreira, 2019).

It is strongly suggested to use the three stages of learning recommended by the Case Method: prior individual preparation; small group discussion; and plenary discussion.

The prior individual preparation implies the advance distribution of the case to the students. It is suggested that the case be made available at least a week in advance. If the teacher considers it appropriate, he may include a set of assignment questions in the Syllabus to stimulate the reflection process in the stage of prior individual preparation of the students.

The case can be worked on in classes of 80 (or 120) minutes. The teacher must establish a time distribution plan, considering the typical distribution of class schedules of the higher education institution.

Opening the plenary discussion - slides 1 and 2 of the proposed table (Appendix) - may require 15 (or 20) minutes. Then, the teacher can reserve a period of 30 (or 40) minutes for students to discuss the case in small groups before the plenary discussion. If the teacher so prefers, he can make available the assignment questions immediately before the small group discussion begins. The discussion of the case questions - slides 3 to 5 of the proposed table (Appendix) - can consume 30 (or 50) minutes. It is recommended to reserve the remaining 5 (or 10) minutes for the closing of the plenary discussion.

\section{OPENING OF CASE DISCUSSION IN PLENARY}

The opening of the discussion can be used so that the students discuss the institutional attributions and missions of the police agencies in addition to what is foreseen in a concise form in the constitutional text, in its article 144 (Constituição da República Federativa do Brasil, 1988):

"144. Public security, the duty of the state, the right and responsibility of all, is exercised for the preservation of public order and the safety of persons and property, through the following bodies: ... IV - civil police; $\mathrm{V}$ - military police and military fire departments. ..."

" $\$ 4$ The civil police, headed by career precinct police chiefs, is responsible, except for the competence of the Union, for the functions of the judicial police, and the investigation of criminal offenses, except for the military.

$\$ 5$ The military police is responsible for the overt police and the preservation of public order; military fire brigades, in addition to the duties defined by law, are responsible for carrying out civil defense activities.

$\$ 6$ The military police and military fire brigades, auxiliary forces, and army reserve are subordinate, together with the civil police and the state and district criminal police, to the Governors of the States, the Federal District, and the Territories.

$\$ 7$ The law will discipline the organization and functioning of the bodies responsible for public security, to guarantee the efficiency of their activities."

To stimulate discussion at the opening of the session, we suggest the following questions: (a) What elements of information can be provided by overt policing — activity developed by uniformed military police - to assist in conducting or opening a police inquiry? Answers tend to come from students more familiar with the civil police. Then, the teacher can propose the following question: (b) What are the elements of information that can be provided by the area's police station to assist the work of the overt policing? The teacher can use slides 1 and 2 simultaneously to register the contributions of the students. In groups unfamiliar with police work, it is suggested to add the question: (c) What elements of information can be provided by the community that can support overt policing and investigative activities? 
In this case, the answers tend to be based on the reflections produced from reading the article about the co-production of public safety, and the experience of each one in possible interactions with police officers.

\section{DISCUSSION QUESTIONS}

The following is a set of questions (discussion questions) that can be used to support the analysis of the case during the stage of plenary discussion:

1. How can the exchange of information between the civil police and the military police be made institutional in the scope of the operation, and not only between intelligence and/or high-level channels?

2. Is it necessary to change the police organization, be it the civil police or the military police, for this institutionalization to occur?

3. Is a change in the culture of the police necessary for this exchange of information to take place effectively?

\section{CASE ANALYSIS}

Throughout the narrative of the case, it is possible to note the difficulty of Dr. Gabriel and Major Barreto in creating spaces for exchanging information between the operators of the police station and the UPP. They seek this interaction first in a personalized way, then with the support of the Secretariat of Security, but the project still has difficulties to maintain itself, and loses breath with time, despite good results achieved.

The fundamental question that is present, and will be the focus of the discussion of the case, is whether this exchange of information is hampered by the form of organization of the police, one focused only on investigation and the other only on publicity and prevention, or even the police culture in which some of its members already recognize themselves as belonging to separate institutions, or whether, despite this organization determined by the constitutional text, integration within the scope of the operation is possible, desirable, and viable, in order to seek immediate consequences in serving the citizen. This context also allows us to analyze how much individuals can influence institutional changes, and, above all, make them perennial in their organizations.

In this sense, institutional theory offers a relevant theoretical repertoire to analyze the capacity of protagonists to influence their institutions, as well as to understand their limitations in making the Integrated Information Circle experience a practice institutionalized and continuous.

Institutional theory is focused on the study of the behavior of organizations, and "has gained prominence as a popular and powerful explanation for individuals and organizations" (Dacin, Goodstein, \& Scott, 2002, p. 45).

For Chaerki, Ribeiro and Ferreira (2019), this theory helps us realize the importance of the relational aspects of the organizational environment, including the normative and cultural ones, and not just focus on material elements, such as competition for resources. This approach illuminates both the relevance of the articulation between the symbolic and practical dimensions and the role of individual actors who eventually influence the creation and maintenance of institutional systems.

The case under study presents the experience of managers who seek to influence the way their institutions interact, considering the system of rules in which they are inserted. The institutional theory problematizes this context and can be used in conjunction with the case to analyze similar situations that occur in different organizations, as well as in understanding its potentials and limitations.

One of the possible considerations lies in the fact that any institution is dynamic, and incorporates changes that occur both through small movements promoted by isolated actors or groups or through more drastic disruptions. Identify how the individual's capacity for agency expresses itself and intervenes in these processes is important to analyze the potential for change of these initiatives and their institutionalization.

In this approach, it is also relevant to know not only if the agent intends to perform something new, but if he have the power to do it. In this sense, it is possible to verify that institutional change, according to Dacin, Goodstein and Scott (2002), pode ocorrer:

"from the most micro-interpersonal and suborganizational levels to the most macro-social and global levels. It can occur in relatively brief and concentrated periods or when overtime is measured in decades or centuries. And it can happen incrementally, so that observers and participants hardly notice any change, or abruptly, in dramatic episodes that present large discontinuities with previous patterns" (Dacin, Goodstein, \& Scott, 2002, p. 48).

The case reveals interesting discussion points about how much power the protagonists have to implement their ideas, as well as some developments and unexpected events, such as the materialization of a police investigation based on information produced by the Integrated Information 
Circle, established among the police of UPP Rocinha and DP Rocinha, which generated more arrests than expected, and which did not would be possible without this experience of institutional integration.

According to Chaerki et al. (2019), the unintended result is another point of the institutional theory that helps in the interpretation of the continuity or discontinuity of initiatives. It resides in the understanding that in addition to what the agent sought to implement, there are unintended consequences of its action, which occur independently of its will and intention.

The authors also indicate that we need to pay attention to the symbolic dimension, since an institution can be considered as a perennial and dynamic social system, result of social interaction and composed of patterns, expectations models, and symbolic elements accepted as legitimate in a given environment, time, and space (Chaerki et al., 2019).

This approach contributes to the analysis of the case, because from this perspective the work of the police is not limited to what is provided for in the constitutional text, but encompasses a whole set of social expectations about the performance of the civil and military police. The larger the understanding that the activities of the police, or any other type of institution, are in tune with a socially constructed system of beliefs, values, and norms, the greater will be the legitimacy of these organizations.

It so happens that there is a discussion about the role of the police and its alignment with the expectations of society. For Cano (2006), there is an authoritarian heritage that considers the police as:

"an organ of protection of the state and of the elites that ran it, against the citizens who posed a danger to the status quo, the so-called 'dangerous classes.' The transition from the model of a citizen control police to a police to protect the people is gradual and has not yet been completed. Furthermore, the Brazilian state conserves remnants of its oligarchic formation, such as the special prison for people with university education ..." (Cano, 2006, p. 141).

In addition, state police were formed by separating overt policing activities, which belongs to the military police, and investigation, which belongs to the civil police. That division forced some states to establish, according to Cano (2006), "attempts to integrate the work of the military and civil police ... have taken measures to integrate in practice the work of the two corporations. The state of Pará, for example, created a joint academy for the two police forces, without, however, unifying them, so that the coexistence between them could, from the beginning of their training, help overcome mistrust and disagreement. Other states, such as Minas Gerais and Rio de Janeiro, established joint security areas for the two police forces, thus obliging that the geographic jurisdictions of the two institutions - battalions of the military police and civil police stations - coincided, for the first time, in an attempt to promote joint work. Until now, the degree of success of this initiative is quite modest" (Cano, 2006, p. 144).

This integration would seek to bring the military police, which carries out policing on the streets, closer to the civil police, which forwards the notary public and case investigation procedures brought by the military police and other complaints brought directly by the community. Yet, there are resistances to this complementary action, which according to Mathias (2012) can be summarized as follows:

"There are several arguments against the effectiveness of integration between the military and the civil police, namely: the unproductiveness in the division of responsibility between two police managements; two police officers with different patterns of professional behavior, different hierarchical structures and subject to different norms acting in the same area; dual apparatus, which in turn demands excessive expenditures on investments and costs; duplication of staff, facilities, equipment, administrative and operational structures; unification of legislation; compatibility of organizational structures; common disciplinary code; hierarchical and salary equivalence; integrated centers of operation; common areas of training, among other aspects" (Mathias, 2012, p. 101).

The case under study reveals an attempt to overcome these resistances, and its protagonists could be associated with the notion of institutional entrepreneurs, defined as those "actors with an interest in specific institutional arrangements and who mobilize resources to create new institutions or transform existing ones" (Chaerki et al., 2019, p. 74). 
Question 1: How to institutionalize the exchange of information elements between the civil police and the military police within the scope of the operation, and not just between intelligence and/or high-ranking channels?

It is recommended that the teacher encourage students to discuss the institutionalization of information exchange between agencies within the scope of operation based on the following transition issue:

QT1 - What channels can be used so that this information - pointing to the record of the contribution of students on slides 1 and 2 - is exchanged with the necessary speed and without depending on personal relationships between managers?

The teacher should consider that although there is, in many situations, as in the present case, a good relationship between managers, that is, a good personal relationship between commanders and precinct police chiefs, the relationship of the top and lower levels may be far from the relationship expected. The consequence of this is an inadequate exchange of information, which can have a direct impact on the fight against local crime.

Fluidity and dynamism in the exchange of information elements are considered essential for a better 'understanding' of the performance of local trafficking (example: new action of criminality that is no longer found with quantities of drugs that characterize trafficking), the 'identification' of criminals (example: removal of the anonymity of trafficking members), and the 'elaboration of strategies' in the repression of crime (example: investment in an efficient integrated action and not only through routine patrolling with possible armed clashes when criminals are found in the act of committing an offense).

The integration between the agencies creates a favorable environment for the emergence of new channels for the exchange of information. Among these channels, we can have the creation of collection instruments; the formatting of documents that systematize the information collected daily; moments of exchange between agents with more detailed reports; return from the police station of the issued arrest warrants, and criminals operating in the region. Without these forms of systematization, information can be lost or become disconnected.

At this point in the discussion, the difficulty to promote changes in organizations can be problematized, bringing institutional theory as a theoretical repertoire that contributes to analyzing the potentials and limitations that the protagonists had to institutionalize the experience they proposed. This approach can be extended to the analysis of institutionalization processes of change in various forms of organization, not just the police.

\section{Question 2 - Is it necessary to change the police organization, be it the civil police or the military police, for this institutionalization to occur?}

It is recommended that the teacher encourage students to discuss whether the constitutional form of organization of state police forces influences the exchange of information between agencies at the operational level based on the following transition issue:

QT2 - Considering the suggestions mentioned recorded on slide 3 -, are there any indications that require changes in the organization of any of the police? Which are?

Different historical, political, and social contexts have promoted different configurations of security forces around the world. One of the most peculiar systems in terms of police organization is the Brazilian one.

This is because in Brazil the police with the greatest number of officers is the state and, unlike what happens in most security agencies in the world, none of them is capable of promoting prevention and repression in a complete way (Bayley, 2002).

Articulating these two purposes in the same police is equivalent to say that this agency is an institution that performs the full cycle, that "performs all phases of police activity: prevention, repression, investigation, and investigation of crimes" (Silva, 2003, p. 417). This is not the case with the civil police and the military police in the Brazilian context.

It is said then that in Brazil public security has a dichotomous model of police in the states, not because there is more than one police, which occurs in practically all countries, but because each of the two police institutions only goes to a certain extent in the work (Lima, 1989).

Rolim (2007) classifies the Brazilian model as twoparty:

"This policing structure, in the center of which is a 'bi-partition,' produced the peculiar reality of the existence of two policemen in the states that must each make half of the 'policing cycle.' In other words, each state police is, conceptually, police in half because it either investigates or performs overt policing tasks. One makes arrests, the other collects evidence; one patrol, the other receives complaints, etc." (Rolim, 2007, p. 12). 
Also in an atypical way, there is no local police in Brazil, but municipal guards - or also called civil guards - that, even more formally and substantially approaching local police, are still not considered by the constitutional text. Even if they are officially recognized as local police, they will not be agencies that will carry out the full policing cycle. Only the federal police and federal highway have this role. However, with much smaller numbers, and with a continental country as a constituency (see Art. 144 in Annex 1).

At this point, the difficulty in promoting evolutionary changes can be brought in normatively rigid environments. It can be discussed how much the process of institutionalization of practices that seek to redefine organizational parameters tends to suffer resistance without having the merit of its content evaluated as to the potential of institutional improvement.

\section{Question 3 - Is it necessary to change the culture of the police for this exchange of information to occur?}

It is recommended that the teacher encourage students to discuss whether the culture of the two bicentennial police forces the exchange of information between agencies or is a barrier, based on the following transition issue:

QT3 - Because of the observations made on organizational changes - recorded on slide $4-$, is it necessary to foster changes in the culture of the police to make this exchange of information feasible? Which are?

Brazilian police institutions were born separately, reproducing the Iberian model, and have remained so, creating distinct identities (Holloway, 1997). The military police continued with its preventive role and still today serves as an auxiliary force for the Army. The civil police, in turn, was built based on an inquisitorial bureaucratic model (Lima, 1995).

With these premises, the day-to-day police work of each of these agencies was configuring very specific ways of acting among the members of these institutions. It is the socalled police culture or police ethos, which differs depending on whether the police officer is civil or military (Poncioni, 2014).

As the state police have this institutional separation very well demarcated, the police culture also operates in this way. In other words, the military police and the civil police have different cultural traditions and aspects. This may eventually contribute to isolated and competing actions, instead of complementary and cooperative planning. Thus, the biggest challenge lies in the development of strategies that allow the partnership between these institutions, and that can integrate their activities precisely because each one does not complete the entire policing cycle. This is what makes the exchange of information and cooperation between them fundamental, as one of the assumptions for more effective productivity to the services they provide to society.

This point of discussion also allows us to observe that the cultural environment often is not considered in understanding how the organization is perceived by society. The case allows us to analyze the relationship of social expectations with the resistance that proposals for change suffer to be institutionalized.

\section{CLOSURE OF THE CASE DISCUSSION}

It is worth noting that a case for teaching does not have right or wrong answers. This is, firstly, a discussion on the recognition of the importance of exchanging information at the level of units that are directly providing services to the population. Secondly, it is a discussion on what would be the ways to make this exchange of information viable and to recognize any barriers, be they organizational or cultural.

Based on this discussion, it is possible to think of ways of effectively integrated action, respecting the organization and culture of the police, and contributing to the exchange of information between institutions not only at the strategic level, but mainly at the operational level between the units of both the police.

The study of these elements allows the use of institutional theory as a theoretical reference, which contributes to the analysis of change processes in organizations, and the extent to which individuals can influence practices that will become perennial and that improve the service provided.

\section{ALTERNATIVE USE OF THE CASE}

Although the case was originally designed to be used in the CBL (Case-based Learning) perspective, if the teacher so prefers, the case can also be used in the PBL (Problem-based Learning) perspective. To make this possible, we suggest the use of the RPG (Role-playing Game) pedagogical technique, by organizing the students in pairs, with one student having to assume the role of PMERJ senior officer and the other taking the role of PCERJ precinct police chief.

To start the dynamic, the teacher could formulate the following work proposal for students:

At a recent meeting of the public security summit, the Integrated Information Circle held in the Rocinha area between 2015 and 2016 was presented as 'good practice,' 
and decision-makers chose to resume the project. A senior officer from PMERJ and a precinct police chief from PCERJ will be appointed to present an updated joint plan based on that experience. The first step of this team will be to suggest elements of information that the local police can offer to assist in the construction of the police inquiry, as well as indicate elements that the police station in the area can share to assist the development of overt policing.

Another possibility, if the teacher so wishes, is to choose to cut the current case, reserving the section 'Lack of breath' to be given to students during the discussion plenary to forward the case closure discussion.

\section{REFERENCES}

Bayley, D. H. (2002). Padróes de policiamento (2. Ed.). São Paulo: EDUSP.

Cano, I. (2006). Políticas de segurança pública no Brasil: Tentativas de modernização e democratização versus a guerra contra o crime. Revista Internacional de Direitos Humanos, 3(5), 136-155. https://doi.org/10.1590/S1806-64452006000200007

Chaerki, K. F., Ribeiro, G., \& Ferreira, J. M. (2019). Uma introdução à teoria institucional do ponto de vista sociológico. Caderno de Administração, 27(1), 62-91. https://doi.org/10.4025/cadadm.v27i1.48409

Constituição da República Federativa do Brasil de 1988. (1988). Constituição da República Federativa do Brasil de 1988. Brasília: Câmara dos Deputados. Retrieved from http:// www.planalto.gov.br/ccivil 03/constituicao/constituicao. $\underline{\mathrm{htm}}$

Dacin, M. T., Goodstein, J., \& Scott, W. R. (2002). Institutional theory and institutional change: Introduction to the special research forum. Academy of Management Journal, 45(1), 43-46. https://doi.org/10.5465/amj.2002.6283388

Holloway, T. H. (1997). Polícia na cidade do Rio de Janeiro: Repressáo e resistência numa cidade do século XIX. Rio de Janeiro: Editora FGV.

Lima, R. K. (1989). Cultura jurídica e práticas policiais: A tradição inquisitorial no Brasil. Revista Brasileira de Ciências Sociais, 4(10), 65-84. Retrieved from https://app.uff.br/riuff/handle/1/9052
Lima, R. K. (1995). A polícia da cidade do Rio de Janeiro: Seus dilemas e paradoxos. Rio de Janeiro: Forense.

Martins, I. M., Farias, J. S., \& Angelo, L. A., Junior. (2019). Segurança cidadã: Formas de envolvimento e propensão do cidadão à coprodução de segurança pública no Distrito Federal. Contextus - Revista Contemporânea de Economia e Gestão, 17(2), 160-189. https://doi.org/10.19094/contextus.v17i2.41013

Mathias, N. R. (2012). A integração da polícia militar e polícia civil do estado do Amazonas com o advento do plano de revitalização da segurança pública. Revista Cientifica de Pesquisa em Segurança Pública da Polícia Militar de Mato Grosso (PMMT), 8, 96-120. http://revistacientifica. pm.mt.gov.br/ojs/index.php/semanal/article/view/183/0

Poncioni, P. (2014). Identidade profissional policial. In R. S. de Lima, J. L. Ratton, \& R. G. de Azevedo (Orgs.), Crime, polícia e justiça no Brasil. São Paulo: Editora Contexto.

Rolim, M. (2007). Análises e propostas: A segurança como um desafio moderno aos direitos humanos. São Paulo: Fundação Friedrich-Ebert.

Secretaria de Estado de Segurança do Rio de Janeiro. (2015). Unidade de Polícia Pacificadora - UPP: Da origem do programa à politica de pacificaçâo. Rio de Janeiro: SESEG. Retrieved from https://www.academia.edu/39198993/ Unidade de Polícia Pacificadora UPP da origem do programa à política de pacificaçáo

Silva, J. (2003). Segurança pública e polícia: Criminologia crítica aplicada. Rio de Janeiro: Editora Forense. 


\section{Authorship}

\section{Leonardo Mazzurana*}

Fundação Centro Estadual de Estatísticas, Pesquisas e Formação de Servidores Públicos do Rio de Janeiro, Escola de Gestão e Políticas Públicas

Av. Carlos Peixoto, n. 54, Botafogo, 22290-090, Rio de Janeiro, RJ, Brazil

E-mail: leonardomzv@gmail.com

(D) https://orcid.org/0000-0003-3012-1463

\section{Victor Almeida}

Universidade Federal do Rio de Janeiro, Instituto COPPEAD de Administração

Rua Pascoal Lemme, n. 355, Cidade Universitária, 21941-918, Rio de Janeiro, RJ, Brazil

E-mail: valmeida@coppead.ufrj.br

(D) https://orcid.org/0000-0002-4433-0787

* Corresponding Author

\section{Funding}

The authors reported that there is no financial support for the research in this article.

\section{Conflict of Interests}

The authors have stated that there is no conflict of interest.

\section{Copyrights}

RAC owns the copyright to this content.

\section{Authors' Contributions}

$1^{\text {st }}$ author: conceptualization (lead); investigation (lead); project administration (supporting); writing-original draft (equal); writing-review $\&$ editing (equal).

$2^{\text {nd }}$ author: methodology (lead); project administration (lead); writing-original draft (equal); writing-review \& editing (equal).

\section{Plagiarism Check}

The RAC maintains the practice of submitting all documents approved for publication to the plagiarism check, using specific tools, e.g.: iThenticate.

\section{Peer Review Method}

This content was evaluated using the double-blind peer review process. The disclosure of the reviewers' information on the first page, as well as the Peer Review Report, is made only after concluding the evaluation process, and with the voluntary consent of the respective reviewers and authors.

\section{Data Availability}

RAC encourages data sharing but, in compliance with ethical principles, it does not demand the disclosure of any means of identifying research subjects, preserving the privacy of research subjects. The practice of open data is to enable the reproducibility of results, and to ensure the unrestricted transparency of the results of the published research, without requiring the identity of research subjects. 


\section{APPENDIX A}

\begin{tabular}{|c|c|c|c|c|}
\hline Whiteboard 1 & Whiteboard 2 & Whiteboard 3 & Whiteboard 4 & Whiteboard 5 \\
\hline $\begin{array}{l}\text { How policing can } \\
\text { contribute to the civil police } \\
\text { investigation? }\end{array}$ & $\begin{array}{l}\text { How civil police } \\
\text { investigations can contribute } \\
\text { to the policing? }\end{array}$ & $\begin{array}{l}\text { What channels can be used } \\
\text { to facilitate the exchange of } \\
\text { information? }\end{array}$ & $\begin{array}{l}\text { Is it necessary any change in } \\
\text { the organization of the police } \\
\text { to build these channels? }\end{array}$ & $\begin{array}{l}\text { Is there any need to change } \\
\text { the police culture in order to } \\
\text { consolidate these channels? }\end{array}$ \\
\hline $\begin{array}{l}\text { - Reports } \\
\text { - Information about armed } \\
\text { confrontations } \\
\text { - Approaches to people } \\
\text { - } \quad \ldots\end{array}$ & $\begin{array}{l}\text { - Information about arrest } \\
\text { warrants } \\
\text { - Mapping of areas with a } \\
\text { large number of armed } \\
\text { confrontations } \\
\text { - Photos of wanted } \\
\text { criminals }\end{array}$ & $\begin{array}{l}\text { - Standard operational } \\
\text { protocols } \\
\text { - Periodic meetings } \\
\text { between teams } \\
\text { - Joint reports } \\
\text { - Articulation with the } \\
\text { local community } \\
\text { - ... }\end{array}$ & $\begin{array}{l}\text { - Greater decentralization } \\
\text { - Change in the } \\
\text { dissemination of } \\
\text { information } \\
\text { - Change in information } \\
\text { management } \\
\text { - Institutionalization of } \\
\text { good habits } \\
\text { - Support to initiatives of } \\
\text { - innovation } \\
\text { - ... }\end{array}$ & $\begin{array}{l}\text { - Change competition view } \\
\text { - Integration as a value } \\
\text { - Citizen as a focus } \\
\text { - Recognize the expectation } \\
\text { about the work done by } \\
\text { the police } \\
\text { - ... }\end{array}$ \\
\hline
\end{tabular}

Figure A1. Proposed framework. 